Vladimir Tamindžić, advokat Milovan Đokovic, dipl. pravnik

\title{
PRAVNE POSLEDICE BRISANJA PRIVREDNOG DRUŠTVA IZ REGISTRA*
}

\author{
Prvi deo \\ POSTAVLJANJE PROBLEMA
}

Prema odredbama iz člana 452. stav 2. Zakona o privrednim društvima (,Sl. glasnik” RS broj 125/04) postojeća privredna društva, preduzetnici i drugi oblici povezivanja i organizovanja za obavljanje privredne delatnosti dužni su da pravnu formu, organe, akcionare i članove, osnovni kapital, akcije i udele, poslovno ime, memorandume, delove preduzeća sa određenim ovlašćenjima u pravnom prometu kao i svoje opšte akte i osnivačke ugovore usklade sa odredbama ovog zakona u roku od dve godine od dana stupanja na snagu Zakona.

U stavu 4. istog člana predviđeno je da privredna društva, preduzetnici i drugi oblici povezivanja i organizovanja za obavljanje privredne delatnosti koji ne postupe na način i u roku iz stava 2. ovog člana prestaju sa radom posle sprovedenog postupka likvidacije o trošku subjekta likvidacije, koji po službenoj dužnosti pokreće Registar privrednih društava i brišu se iz Registra.

Prema odredbi iz člana 347. stav 1. tačke 4. i 5. Zakona o privrednim društvima likvidacija se sprovodi nad privrednim društvom ako nije organizovano u skladu sa Zakonom a ako ne obavlja delatnost duže od dve godine neprekidno. Kako je pomenuti rok od dve godine prošao postavljaju se praktična pitanja:

- kakve su pravne posledice u parnicama koje su vođene prema tuženim društvima koja su brisana iz Registra privrednih društava,

* Rad primljen: 20. I 2007. godine. 
- šta sa izvršnim postupkom koji je započet prema privrednim društvima koja su posle donošenja rešenja o izvršenju brisana uz Registra privrednih društava,

- ako je doneta pravnosnažna i izvršna presuda može li se i kako sprovesti izvršenje prema dužniku koji je brisan iz Registra odnosno na njegovoj imovini.

\section{PRAVNE POSLEDICE PRESTANKA PRIVREDNOG DRUŠTVA U PARNICI}

Kad je privredno društvo brisano iz Registra privrednih društava sud će prekinuti postupak u skladu sa odredbom iz člana 214. stav 1. tačka 4. ZPP-a jer je stranka prestala da postoji.

Odredbom iz člana 217. ZPP-a nije predviđeno izričito da će se postupak nastaviti kada se stranki postavi privremeni zastupnik ali širim tumačenjem svakako i taj slučaj valja uzeti kao razlog za nastavljanje postupka. Ovo prvenstveno iz razloga predviđenog u članu 217. stav 1 . ZPP-a da sud na predlog protivne strane poziva drugu stranu da postupak nastavi.

Mogućnost da se nastavi parnični postupak prema privrednom društvu koje je brisano iz Registra postavljanjem privremenog zastupnika nalazimo u odredbi iz čl. 79. ZPP-a.

Prema članu 73. ZPP-a sud može izuzetno sa pravnim dejstvom u određenoj parnici da prizna status stranke u onom obliku udruživanja i organizovanja koji nemaju stranačku sposobnost ako utvrdi da ispunjavaju bitne uslove za priznavanje stranačke sposobnosti a naročito ako raspolažu imovinom na kojoj se može sprovesti izvršenje.

Na pitanje da li se društvu brisanom iz Registra privrednih društava može priznati oblik udruživanja i organizovanja, što je u smislu člana 73. ZPP-a uslov za priznavanje svojstva stranke, smatramo da treba pozitivno odgovoriti ukoliko postoji imovina društva.

Treba povezati priznavanje svojstva stranke u postupku prema čl. 73 . ZPP-a i postavljanje privremenog zastupnika po čl. 79. ZPP-a.

Prvo bi valjalo kod suda izdejstvovati priznavanje svojstva stranke a zatim postavljanje privremenog zastupnika od strane suda.

Razume se da se to u praksi može tražiti jednim podneskom.

Imovina svakako podrazumeva neku vrstu organizovanosti u smislu korišćenja registrovanja, održavanja i očuvanja stvari i prava.

\section{PRAVNE POSLEDICE PRESTANKA PRIVREDNOG DRUŠTVA U IZVRŠNOM POSTUPKU}

Prema odredbi iz čl. 27. ZIP u izvršnom postupku se shodno primenjuju odredbe ZPP-a. 
Prema tome, privremeni zastupnik ranijem - brisanom privrednom društvu može se postaviti kako je napred navedeno i tražiti nastavljanje izvršnog postupka.

Sve napred rečeno važi pod uslovom da postoji imovina privrednog društva koja je preostala posle brisanja iz Registra privrednih društava.

\section{Drugi deo}

Privredno društvo je pravno lice (član 2. stav 1. ZPD), koje to svojstvo stiče unošenjem podataka o privrednom društvu u Registar privrednih subjekata, kao što je propisano u članu 8. Zakona o privrednim društvima.

Prestanak privrednog društva je uređen Zakonom o privrednim društvima i Zakonom o registraciji privrednih subjekata, te drugim zakonima na koje upućuje Zakon o privrednim društvima.

Razlozi za prestanak privrednog društva su utvrđeni Zakonom o privrednim društvima i Zakonom o registraciji privrednih društava za slučaj proteka određenog vremena od momenta prevođenja privrednog društva u status neaktivnog privrednog društva.

Prestanak privrednog društva nastupa brisanjem privrednog društva u Registru privrednih subjekata, iako o tome nema izričite zakonske odredbe.

Brisanje podataka o privrednom društvu, upisanih u Registar privrednih subjekata, vrši se po okončanju i kao rezultat sprovedenog postupka likvidacije uređenog Zakonom o privrednim društvima ili postupka stečaja uređenog Zakonom o stečajnom postupku, na osnovu zahteva likvidacionog upravnika (član 362. stav 1. i 2. Zakona o privrednim društvima), odnosno rešenja stečajnog veća o zaključenju stečajnog postupka koje se po službenoj dužnosti dostavlja Agenciji za privredne registre kao „drugom nadležnom organu" koji vodi Registar u koji su uneti podaci o stečajnom dužniku.

Dakle, prema Zakonu o privrednim društvima i Zakonu o registraciji privrednih subjekata, nema brisanja privrednog društva (svih unetih podataka o privrednom društvu) u Registru privrednih subjekata bez zahteva likvidacionog upravnika, odnosno rešenja stečajnog veća, pa prema tome ni imovine privrednog društva bez titulara prava svojine na toj imovini.

Ipak, ona može da se pojavi:

- kao posledica greške/previda ili zloupotrebe organa nadležnog za sprovođenje postupka likvidacije/stečaja,

- kao posledica greške/previda ili zloupotrebe Registratora, kao lica ovlašćenog i odgovornog za unošenje i brisanje podataka o privrednom društvu u Registru privrednih subjekata.

Za svoje obaveze, privredno društvo odgovara celokupnom svojom imovinom (član 53. stav 2, član 90. stav 2, član 104. stav 2, član 184. stav 2. Zakona o privrednim društvima). 
Prema članu 13. stav 11. Zakona o privrednim društvima, imovinu privrednog društva čini pravo svojine i druga prava koja privredno društvo ima na ulozima, ili je steklo poslovanjem.

Pored privrednog društva, za njegove obaveze prema trećim licima, u određenim slučajevima i u odgovarajućem obimu, odgovaraju i njegovi članovi odnosno akcionari:

- članovi/akcionari odgovaraju za obaveze društva prema trećim licima do iznosa upisanog a neunetog uloga u društvo, odnosno imovinu društva,

- ortaci ortačkog društva i komplementari komanditnog društva odgovaraju trećim licima za obaveze ortačkog, odnosno komanditnog društva, neograničeno solidarno celokupnom svojom imovinom, sa izuzetkom u slučaju u kojem je sa konkretnim poveriocem ta odgovornost isključena,

- i komanditor komanditnog društva odgovara celokupnom svojom imovinom za obaveze tog društva ako je njegovo ime, uz njegovu saglasnost uneto u poslovno ime društva i ako, suprotno zakonu (član 100. stav 2. ZPD) vrši poslovođenje društva.

- Odgovornost komanditora komanditnog društva, člana društva s ograničenom odgovornošću i akcionara akcionarskog društva za obaveze komanditnog društva, društva s ograničenom odgovornošću odnosno akcionarskog društva prema trećim licima postoji i u (1) slučaju zloupotrebe privrednog društva za nezakonite ili prevarne ciljeve, ili (2) ako sa imovinom privrednog društva raspolaže kao sa sopstvenom imovinom, kao da privredno društvo kao pravno lice ne postoji. Odgovornost je solidarna.

- Komanditor $\mathrm{KD}$, članovi DOO i akcionari $\mathrm{AD}$ odgovaraju za obaveze $\mathrm{KD}, \mathrm{DOO}$, odnosno $\mathrm{AD}$ prema trećim licima i tako što imaju obavezu na povraćaj primljenog po osnovu isplata iz likvidacionog ostatka (član 360. stav 3. ZPD).

Njihova obaveza se ne izražava u neposrednom odnosu prema trećem licu/poveriocu, već kroz povraćaj primljenog iz likvidacionog ostatka. Mislimo da su u istom položaju i lica koja su primila isplate iz viška deobne stečajne mase (član 124. Zakona o stečajnom postupku).

Kod slučaja prevođenja privrednog društva u status neaktivnog privrednog društva, mislimo da nema nikakve promene u pogledu odgovornosti takvog društva za obaveze prema trećim licima, jer takvo društvo i dalje postoji pošto prestaje tek činom brisanja koji može da usledi samo po sprovedenom likvidacionom ili stečajnom postupku.

\section{Treći deo}

Prema Zakonu o privrednim društvima privredno društvo nastaje donošenjem/zaključivanjem osnivačkog akta (član 7. stav 1). Podrazumeva se overa potpisa osnivača na osnivačkom aktu kod nadležnog suda (član 7. stav 3). 
Ono postaje pravni subjekt, stiče svojstvo pravnog lica registracijom, tj. upisom (unošenjem propisanih podataka) u Registar privrednih subjekata koji se vodi u Agenciji za privredne registre (član 8. i 9).

Za razliku od dosta precizno uređenog nastajanja privrednog društva, kao pravnog subjekta, Zakon o privrednim društvima ne sadrži normu kojom bi, u istoj ili sličnoj meri, precizno bilo određeno kad privredno društvo, kao pravni subjekt, gubi pravni subjektivitet i time prestaje da postoji.

Ranije važeći Zakon o preduzećima iz 1996. godine imao je takvu normu u članu 100. stav 3, prema kojoj je preduzeće prestajalo brisanjem iz Registra.

Odredbe Zakona o privrednim društvima kojima je uređen prestanak privrednog društva (članovi $80-89,181-182,103$. i $345-346$ ) ne preciziraju momenat prestanka njihovog pravnog subjektiviteta i u njima se i ne pominje brisanje iz Registra privrednih subjekata.

Izuzetak predstavlja odredba člana 52. prema čijoj sadržini i naslovu člana prestanak preduzetnika nastupa njegovim brisanjem iz Registra.

Ipak, imajući u vidu da privredno društvo stiče pravni subjektivitet registracijom u Registar privrednih subjekata, može se zaključiti da se taj, i tako stečeni, pravni subjektivitet gubi brisanjem privrednog društva uređenim Zakonom o registraciji privrednih subjekata (član 72 . stav 2) tj. njegovim prevođenjem u Registru privrednih subjekata u status brisanog subjekta, što se vrši obeležavanjem oznakom „BRISAN”, uz navođenje osnova i vremena brisanja.

Redovan put za prestanak privrednog društva, u navedenom smislu - gubitak pravnog subjektiviteta, je onaj koji je uređen odredbama člana 70. Zakona o registraciji privrednih subjekata - brisanje u Registru privrednih subjekata po službenoj dužnosti po prijavi likvidacionog, odnosno stečajnog upravnika posle sprovedenog postupka likvidacije odnosno stečaja.

U slučaju brisanja privrednog društva po tzv. „službenoj dužnosti” nema mesta postavljanju navedenih praktičnih pitanja, jer je u potpunosti uređeno postupanje sa imovinom tako brisanog privrednog društva. Ona se evidentira, unovčava i raspoređuje prema Zakonu o privrednim društvima (likvidacija), odnosno prema Zakonu o stečajnom postupku (stečaj).

Tim propisima je uređeno i postupanje sa imovinom brisanog privrednog društva za koju se sazna posle okončanja ovih postupaka.

Slična je situacija i kod prestanka privrednog društva zbog ništavosti registracije osnivanja. Razlika je samo u tome što se u ovom slučaju postupak likvidacije, odnosno stečaja sprovodi posle registrovanja ništavosti registracije osnivanja, na osnovu pravnosnažne sudske odluke (član 69. stav 6. Zakona o registraciji privrednih subjekata).

U svakom slučaju i kod brisanja po službenoj dužnosti i kod prestanka zbog ništavosti registracije osnivanja, na strani tuženog postoji stranka koju zastupa likvidacioni upravnik, sve dok se taj postupak ne za- 
vrši, bilo podnošenjem prijave za brisanje iz sudskog registra, bilo obustavljanjem postupka i pokretanjem stečajnog postupka.

Prema članu 68. stav 2. Zakona o registraciji privednih subjekata, Registrator po službenoj dužnosti, briše privredno društvo iz Registra po isteku roka od 12 meseci od dana prevođenja u status neaktivnog privrednog subjekta.

U ovom slučaju, dakle, po isteku 12 meseci od dana prevođenja u status neaktivnog subjekta, ,privredni subjekt se briše iz Registra", što znači da brisanju ne prethodi ni postupak likvidacije, niti stečajni postupak.

Prevođenje privrednog društva u status neaktivnog privrednog subjekta Registrator vrši, takođe po službenoj dužnosti (1) zbog neizvršavanja dužnosti propisane odredbom člana 82. i 83. Zakona o registraciji privrednih subjekata (nepodnošenje prijave/zahteva za prevođenje iz sudskog registra u Registar privrednih subjekata) i (2) zbog nedostavljanja Registru godišnjeg finansijskog izveštaja dve godine uzastopno (član 67. stav 1. Zakona), imajući pritom u vidu da je obaveza registracije tih izveštaja u Registru privrednih subjekata nastala sa 01. januarom 2006. godine.

U vezi sa ovim brisanjem (brisanje po službenoj dužnosti) privrednog društva u Registru privrednih subjekata postavljalo se pitanje sudbine imovine tako brisanog privrednog društva, odnosno sudbine nerealizovanih potraživanja poverilaca tog privrednog društva.

Radi zaštite interesa pravnih sledbenika brisanog privrednog društva i njegovih poverilaca, Vlada Republike Srbije je za sprovođenje člana 68. stav 2. Zakona o registraciji privrednih subjekata donela Uredbu o postupanju državnih organa, organizacija i pravnih lica prema neaktivnim privrednim subjektima brisanim iz Registra privrednih subjekata (,Sl. glasnik RS" br. 49/06 - 08. 06. 2006).

Ovom Uredbom je propisano:

1. da danom brisanja iz Registra privrednih subjekata prestaje pravna i poslovna sposobnost neaktivnog privrednog subjekta;

2. da se sredstva brisanog privrednog subjekta koja se u momentu brisanja nalaze na njegovom računu kod banke, prenose na poseban račun;

3. da se plaćanje obaveza prema brisanom privrednom subjektu, po pravnom osnovu koji je nastao pre njegovog brisanja, vrši prema propisima vanparničnog postupka u delu koji se odnosi na sudski depozit;

4. da nadležni državni organi, organizacije i pravna lica ne mogu da sprovode, registruju, odnosno upisuju raspolaganja imovinom brisanog pravnog subjekta koja su vršena posle njegovog brisanja iz Registra, izuzev ako su se za to bili stekli zakonski uslovi do dana brisanja privrednog subjekta iz Registra;

5. da založna prava na imovini brisanog privrednog subjekta, koja su stečena do dana njegovog brisanja iz Registra, ostaju na snazi. 
Odgovori na pitanja postavljena na početku ovog teksta se mogu tražiti pre svega u odredbi člana 4. navedene uredbe. Naime, kako propisuje uredba, na postupke koji se vode pred sudovima, u kojima je jedna od stranaka brisani privredni subjekt, primenjuju se zakoni kojima se uređuju ti postupci u delu koji se odnosi na prekid, odnosno obustavu postupka. Mi bismo zaključili i na nastavljanje postupka pod uslovima koji su napred izneti. 